\title{
Nineteen-year trends in fermented food consumption and sodium intake from fermented foods for Korean adults from 1998 to 2016
}

\author{
Sang Young Kim ${ }^{1}$ (D), Jeanne H Freeland-Graves ${ }^{1, *}$ and Hyun Ja Kim² \\ 'University of Texas at Austin, Division of Nutritional Sciences, Austin, TX 78712, USA: ${ }^{2}$ Gangneung-Wonju National \\ University, Division of Food and Nutrition, Gangneung, Gangwon-do, Republic of Korea
}

Submitted 16 February 2019: Final revision received 30 May 2019: Accepted 3 July 2019: First published online 4 November 2019

\begin{abstract}
Objective: Fermented foods such as kimchi are traditional foods in Korea and could provide beneficial health effects. However, fermented foods also contribute to increased $\mathrm{Na}$ intake since salt is added during the fermentation process. The present research aimed to examine trends in the consumption of fermented foods and $\mathrm{Na}$ intake over time by Korean adults, using data from the Korea National Health and Nutrition Examination Survey (KNHANES).

Design: KNHANES is a cross-sectional survey; data from 1998 to 2016 were divided into seven groups from KNHANES I to VII.

Setting: Demographic information on sex, age, education and income were collected. Assessment of fermented food and Na consumption was conducted via analysis of $24 \mathrm{~h}$ dietary recall data. Multivariate linear regressions and logistic regressions were performed to calculate the $P$ for trends by applying strata, cluster and sampling weights by SAS PROC SURVEY.

Participants: The target population was Korean adults, aged $\geq 19$ years, who participated in a $24 \mathrm{~h}$ dietary recall. The total number was 76199 , with 32324 men and 43875 women.

Results: A significant decline in fermented food consumption was observed from 1998 to 2016 in both men and women $(P<0 \cdot 0001)$. Among fermented foods, kimchi consumption was greatly reduced while pickled vegetables consumption showed a marked increase. Similarly, Na intake from fermented foods declined significantly over time in both men and women $(P<0.0001)$.

Conclusions: The consumption of fermented foods and $\mathrm{Na}$ intake from fermented foods by Korean adults decreased significantly over time from 1998 to 2016.
\end{abstract}

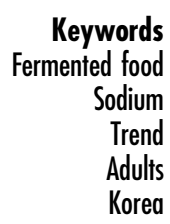

Fermented foods constitute a significant component of the Korean diet. These traditional foods may contribute positive health outcomes, as they have been reported to play a role in the prevention of cancer, obesity, diabetes and constipation $^{(1)}$. During fermentation enzymes are created from micro-organisms such as fungi or bacteria; these enzymes have potential health benefits as they can dissolve blood clots and improve blood circulation in the human body $^{(2)}$. In contrast, fermented foods also contribute substantial amounts of $\mathrm{Na}$ to the diet from salt added during processing and preparation. Also, in the fermentation process for soya, the development of high levels of nitrate or nitrite and the loss of substantial nutrients could increase the risk of gastric cancer ${ }^{(3)}$.
High intake of $\mathrm{Na}$ is known to promote or exacerbate hypertension $^{(4)}$, a disease that is prevalent in both Korea and the USA. Hypertension is a well-known risk factor for CHD, stroke and kidney disease; and the onset of hypertension increases dramatically with age ${ }^{(5)}$. The prevalence for Korean adults has increased from $32.4 \%$ in men in 1998 to $35.0 \%$ in 2016. In women, it has declined from 26.8 to $22.9 \%$ over the same time period ${ }^{(6)}$. In comparison, the prevalence of hypertension in the USA has increased slightly in men aged $\geq 18$ years ( 28.7 to $30 \cdot 2 \%$ from $1999-2000$ to $2015-$ 2016); in women, it has declined slightly, $28 \cdot 3$ to $27 \cdot 7 \%{ }^{(7,8)}$. However, hypertension was not related to consumption of kimchi, the most popular fermented food in Korea, according to an analysis of the 2007-2012 Korea National Health and 
Nutrition Examination Surveys (KNHANES) ${ }^{(9)}$. One plausible reason may be that kimchi is rich in $\mathrm{K}$, as well as $\mathrm{Na}$, such that high ingestion of $\mathrm{K}$ may counteract effects of excess dietary $\mathrm{Na}^{(9)}$. Additionally, Koreans consume a number of other fermented foods that also may influence health. The goal of the present research was to assess fermented food consumption and $\mathrm{Na}$ intake among Korean adults using 1998-2016 KNHANES data and to discern changes over time.

\section{Methods}

\section{Study design}

The present research is a secondary analysis of the data from KNHANES, conducted by the Korea Centers for Disease Control and Prevention (KCDC) ${ }^{(10)}$. KNHANES is a cross-sectional survey to evaluate the health and nutritional status of the Korean population using a stratified and multistage sampling design. The three components of KNHANES are a health examination, a health interview and a nutrition survey. KNHANES was established in 1998; the 2016 KNHANES data are the most recent open-source data available and were released in January 2018. Initially, the surveys were conducted triennially for 1998, 2001 and 2005; in November and December of 1998 and 2001, and April-June in 2005. However, the system was transformed to collect the surveys annually throughout the year starting in 2007 in order to deliver the information in a timely manner. Yet, the data for 3 years are considered a set due to the fact that the sample size per year became smaller from 2007 than the triennial data for 1998, 2001 and 2005. Thus, the present research utilized a KNHANES data set from 1998 to 2016, divided into seven categories based on a suggestion by the KCDC. The data sets used were: 1998 (KNHANES I), 2001 (KNHANES II), 2005 (KNHANES III), 2007-2009 (KNHANES IV), 2010-2012 (KNHANES V), 2013-2015 (KNHANES VI) and 2016 (KNHANES VII). The survey protocol was approved by the KCDC Institutional Review Board and written informed consent was provided by the participants.

\section{Participants}

Participants in KNHANES were Korean citizens, aged $\geq 1$ year, residing in representative households who were selected using a stratified and multistage clustered probability sampling method. The response rates of the selected population ranged from $70 \cdot 2$ to $86.5 \%$ in each survey. The present research focused solely on Korean adults, aged 19 years or older, who participated in the $24 \mathrm{~h}$ dietary recall from the 1998-2016 KNHANES. It sampled a total number of 76199 participants, 32324 men and 43875 women. These included 7501 in 1998 (KNHANES I), 7092 in 2001 (KNHANES II), 6526 in 2005 (KNHANES III), 16187 in 2007-2009 (KNHANES IV), 17394 in 2010-2012 (KNHANES V), 16069 in 2013-2015 (KNHANES VI) and
5430 in 2016 (KNHANES VII). The adult population was divided into four age groups: 19-29 years, 30-49 years, $50-64$ years and $\geq 65$ years, based on the criteria from the 2015 Dietary Reference Intakes for Koreans ${ }^{(11)}$.

\section{Dietary intake assessment}

The present research analysed $24 \mathrm{~h}$ dietary recall data from 1998 to 2016 KNHANES in order to identify the daily amount of food consumption, with respect to nutrient intake. As part of the overall survey and face-to-face interview process, a trained dietitian visited the homes of participants to conduct the nutrition survey. The $24 \mathrm{~h}$ dietary recall provided information on types, quantities, volumes and weight of foods that were consumed within the previous $24 \mathrm{~h}$. Each type of ingredient, the amount of each ingredient, cooking method and total amount of food after being cooked were assessed by the person who prepared the food. Then, this information was applied to each household member for type and amount of each food consumed. Seasonings or processed foods utilized during preparation were measured, differentiated by brand name. The volume of food was determined by the size of bowl/dishes used and changed to weight using the database for volume-weight conversion ${ }^{(12)}$. The open-source data were analysed to examine the consumption of fermented foods and their Na content. Fermented foods were divided into six categories: (i) kimchi; (ii) fermented red pepper paste; (iii) fermented soyabean paste; (iv) soya sauce; (v) saltfermented seafood; and (vi) pickled vegetables. In Korea, fermented red pepper paste, fermented soyabean paste, salt-fermented seafood and pickled vegetables are known as gochujang, doenjang, jeotgal and jangajii, respectively. The total fermented foods indicated the sum of the six categories. The amount of each fermented food item and its $\mathrm{Na}$ content were calculated based on the food composition tables by the Rural Development Administration: 5th edition ${ }^{(13)}$ for 1998 (KNHANES I), 6th edition ${ }^{(14)}$ for 2001 (KNHANES II) and 2005 (KNHANES III), 7th edition ${ }^{(15)}$ for 2007-2009 (KNHANES IV) and 2010-2012 (KNHANES V), and 8th edition ${ }^{(16)}$ for 2013-2015 (KNHANES VI) and 2016 (KNHANES VII).

\section{Statistical analysis}

All analyses were completed with the statistical software package SAS version 9.4 using the PROC SURVEY procedure. Multivariate linear regression and logistic regression were conducted to calculate $P$ for trend with applying strata, cluster and sampling weights. Age was adjusted as a confounding factor. Complex sample design, non-response rate of the target population and poststratification were considered in order to create sampling weights. Multivariate linear regression was applied for continuous variables and multivariate logistic regression for categorical variables. Data for continuous variables were denoted as means with their standard errors; for categorical 
variables, as percentages with their standard errors. Age was standardized based on the 2005 Korea census for all analyses, except for mean age and percentages of each age group. A two-sided $P$ for trend of $\leq 0.05$ was considered to denote statistical significance.

\section{Results}

\section{Characteristics of participants}

The mean age of participants increased over time from 1998 to 2016. There was a decline in the percentage of individuals from the 19-29 years and 30-49 years age groups, with an escalation in individuals from 50-64- and $\geq 65$-year-old groups in both men and women (Table 1). In addition, the percentage of individuals who completed middle school or lower in education level diminished, and individuals who completed college or higher rose in both men and women over time. Household monthly income level increased significantly over time.

\section{Trends in fermented food intake}

Trends in age-standardized fermented food intake from the 1998 to the 2016 KNHANES are shown in Table 2. Noticeable changes in fermented food consumption occurred. Overall, the mean total fermented food intake declined significantly over time. The highest ingestion reported was 207.0 and $169.1 \mathrm{~g}$ in 2001 , and the lowest amount observed was 155.4 and $105.5 \mathrm{~g}$ in 2016, in men $(P<0.0001)$ and women $(P<0.0001)$, respectively. Similarly, the mean kimchi consumption also diminished over time; with a peak of 168.4 and $139.2 \mathrm{~g}$ in 2001 and the lowest amount of 118.4 and $79.8 \mathrm{~g}$ recorded in 2016 in men $(P<0.0001)$ and women $(P<0.0001)$, respectively. Both men and women in the 19-29-year-old group consumed the least amount of total fermented foods and kimchi in the four age groups (Figs 1 and 2). In contrast, the trend for fermented red pepper paste intake increased from 1998 to 2016; however, no trend was found from 2007-2009 to 2016 in men $(P=0.3958)$ and women $(P=0 \cdot 1778)$. On the other hand, the mean fermented soyabean paste intake decreased over time in both men and women. There was a significant decline for soya sauce consumption in women only; the trend was consistent from $2007-2009$ to $2016(P=0 \cdot 7900)$. No tendency was observed in men over time $(P=0.4554)$. The mean intake of salt-fermented seafood decreased consistently over time in men and women. The trend in pickled vegetable intake elevated persistently over time from 1998 to 2016. However, this represented only approximately 3.0 to $9.0 \%$ of the overall fermented food intake. Participants in the 19-29-year-old category consumed the highest amount of pickled vegetables, according to age group (Fig. 3). Pickled yellow radish (danmuji in Korea) was the most popular of the pickled vegetables (highest of $6.0 \mathrm{~g}$ in 2016 for men and $4.3 \mathrm{~g}$ in 2001 for women).

\section{Trends in sodium consumption from fermented food intake}

Trends in age-standardized $\mathrm{Na}$ consumption from fermented food intake are listed in Table 3 and trends in percentage of $\mathrm{Na}$ consumption from fermented foods to total daily $\mathrm{Na}$ intake are described in Table 4. First, the trend for the mean daily intake of total $\mathrm{Na}$ reduced significantly overall, but also fluctuated with a peak of $6400 \cdot 6$ and $4971.2 \mathrm{mg}$ in 2005, and was the lowest in 2016 at 4704.8 and $3171.6 \mathrm{mg}$, for men $(P<0.0001)$ and women $(P<0.0001)$, respectively. The $\mathrm{Na}$ intake from total fermented foods diminished dramatically over time, ranging from $3264.0 \mathrm{mg}$ in 1998 to $1975.0 \mathrm{mg}$ in 2016 for men $(P<0.0001)$ and from 2572.9 to $1351.8 \mathrm{mg}$ for women $(P<0.0001)$. The contribution of $\mathrm{Na}$ intake from total fermented foods to total daily $\mathrm{Na}$ intake declined from 58.8 to $45.4 \%$ in men $(P<0.0001)$ and from 59.4 to $47.0 \%$ in women $(P<0.0001)$. More specifically, the mean $\mathrm{Na}$ intakes from kimchi, fermented soyabean paste and saltfermented seafood, respectively, decreased significantly over time in both men and women. Na intake from kimchi decreased by approximately $63.3 \%$ in men and $69.4 \%$ in women. Na intake from kimchi as part of total daily Na consumption declined from 35.7 to $17.8 \%$ in men $(P<0.0001)$ and from 36.3 to $18.2 \%$ in women $(P<0.0001)$. In contrast, the mean $\mathrm{Na}$ intake from fermented red pepper paste fluctuated, but increased overall. Similarly, an escalating trend was found in the mean $\mathrm{Na}$ intake from pickled vegetables. The mean $\mathrm{Na}$ intake from soya sauce fluctuated, but decreased overall in women; however, there was no trend from 2007-2009 to 2016 ( $P=0 \cdot 1582)$. Unlike women, no change was observed in Na consumption from soya sauce overall in men $(P=0.3754)$. Yet, a consistent decrease was observed from $2007-2009$ to 2016 ( $P=0.0009)$.

\section{Discussion}

These results show that trends in fermented food consumption, particularly kimchi, declined noticeably over time in both men and women, based on the KNHANES from 1998 to 2016.

The trends in total fermented food and kimchi consumption in each age category were similar (Figs 1 and 2), since kimchi contributes the highest percentage to fermented foods consumed in Korea. Estimated energy requirements are highest in Korean young adults (aged 19-29 years); specifically, $10878 \mathrm{~kJ} / \mathrm{d}(2600 \mathrm{kcal} / \mathrm{d})$ for men and $8786 \mathrm{~kJ} / \mathrm{d}$ $(2100 \mathrm{kcal} / \mathrm{d})$ for women ${ }^{(11)}$. However, adults in this age group consumed the least amount of total fermented foods and kimchi, and the trend decreased significantly.

A study by Yon et al. found that kimchi intake was responsible for the highest contribution to Na consumption, $24.5 \%$ of total daily $\mathrm{Na}$ intake, based on the 2008 and $2009 \mathrm{KNHANES}^{(17)}$. In our research, the trend analysis from 1998 to 2016 showed that $\mathrm{Na}$ intake from total 
Table 1 Characteristics of participants, aged $\geq 19$ years, from the 1998 to 2016 Korea National Health and Nutrition Examination Surveys (KNHANES)

\begin{tabular}{|c|c|c|c|c|c|c|c|c|c|c|c|c|c|c|c|c|}
\hline & \multicolumn{16}{|c|}{ KNHANES } \\
\hline & \multicolumn{2}{|c|}{$\begin{array}{c}1 \\
(1998) \\
\end{array}$} & \multicolumn{2}{|c|}{$\begin{array}{c}\text { II } \\
(2001) \\
\end{array}$} & \multicolumn{2}{|c|}{$\begin{array}{c}\text { III } \\
(2005)\end{array}$} & \multicolumn{2}{|c|}{$\begin{array}{c}\text { IV } \\
(2007-2009) \\
\end{array}$} & \multicolumn{2}{|c|}{$\begin{array}{c}V \\
(2010-2012) \\
\end{array}$} & \multicolumn{2}{|c|}{$\begin{array}{c}\text { VI } \\
(2013-2015) \\
\end{array}$} & \multicolumn{2}{|c|}{$\begin{array}{c}\text { VII } \\
(2016)\end{array}$} & \multicolumn{2}{|c|}{$P$ for trend ${ }^{*}$} \\
\hline & $\begin{array}{c}n, \\
\text { mean } \\
\text { or } \%\end{array}$ & SE & $\begin{array}{c}n, \\
\text { mean } \\
\text { or } \%\end{array}$ & SE & $\begin{array}{c}n, \\
\text { mean } \\
\text { or } \%\end{array}$ & SE & $\begin{array}{c}n, \\
\text { mean } \\
\text { or } \%\end{array}$ & SE & $\begin{array}{c}n, \\
\text { mean } \\
\text { or } \%\end{array}$ & SE & $\begin{array}{c}n, \\
\text { mean } \\
\text { or } \%\end{array}$ & SE & $\begin{array}{c}n, \\
\text { mean } \\
\text { or } \%\end{array}$ & SE & $\begin{array}{c}1998 \text { to } \\
2016\end{array}$ & $\begin{array}{l}2007- \\
2009 \text { to } \\
2016\end{array}$ \\
\hline Men & \multicolumn{2}{|c|}{3480} & \multicolumn{2}{|c|}{3253} & \multicolumn{2}{|c|}{2918} & \multicolumn{2}{|c|}{6592} & \multicolumn{2}{|c|}{7129} & \multicolumn{2}{|c|}{6712} & \multicolumn{2}{|c|}{2240} & & \\
\hline Age (years) & $40 \cdot 3$ & 0.3 & $40 \cdot 9$ & 0.3 & $42 \cdot 3$ & 0.4 & 43.5 & 0.3 & 44.5 & 0.3 & $45 \cdot 2$ & 0.3 & $45 \cdot 9$ & 0.5 & $<0.0001$ & $<0.0001$ \\
\hline $19-29$ & $27 \cdot 6$ & 1.0 & $26 \cdot 4$ & 1.0 & 23.0 & $1 \cdot 1$ & $21 \cdot 1$ & 0.8 & $19 \cdot 9$ & 0.8 & 19.5 & 0.7 & $18 \cdot 8$ & 1.3 & $<0.0001$ & 0.1153 \\
\hline $30-49$ & $47 \cdot 4$ & $1 \cdot 3$ & $47 \cdot 3$ & $1 \cdot 2$ & $47 \cdot 7$ & $1 \cdot 3$ & $46 \cdot 0$ & 0.9 & $44 \cdot 0$ & 0.9 & $41 \cdot 3$ & 0.9 & $40 \cdot 4$ & 1.6 & $<0.0001$ & 0.0005 \\
\hline $50-64$ & $17 \cdot 7$ & 0.8 & $18 \cdot 1$ & 0.7 & 19.5 & 0.8 & $21 \cdot 9$ & 0.6 & $24 \cdot 1$ & $0 \cdot 6$ & $26 \cdot 0$ & 0.6 & $27 \cdot 1$ & $1 \cdot 3$ & $<0.0001$ & $<0.0001$ \\
\hline$\geq 65$ & 7.4 & 0.5 & $8 \cdot 2$ & 0.5 & $9 \cdot 7$ & 0.6 & $11 \cdot 1$ & 0.4 & $12 \cdot 0$ & 0.4 & $13 \cdot 2$ & 0.4 & $13 \cdot 7$ & 0.8 & $<0.0001$ & 0.0003 \\
\hline \multicolumn{17}{|l|}{ Education† } \\
\hline$\leq$ Middle school & $29 \cdot 4$ & $1 \cdot 0$ & $26 \cdot 7$ & 0.9 & $22 \cdot 3$ & 0.8 & $23 \cdot 3$ & 0.6 & $20 \cdot 0$ & 0.5 & $17 \cdot 0$ & 0.5 & 14.8 & 0.8 & $<0.0001$ & $<0.0001$ \\
\hline High school & $40 \cdot 8$ & $1 \cdot 1$ & $37 \cdot 1$ & 1.0 & $35 \cdot 8$ & $1 \cdot 1$ & $43 \cdot 2$ & $0 \cdot 8$ & $42 \cdot 8$ & $0 \cdot 8$ & 41.5 & 0.9 & $37 \cdot 0$ & 1.5 & & 0.0027 \\
\hline$\geq$ Coollege & 29.9 & 1.4 & $36 \cdot 1$ & $1 \cdot 1$ & 41.9 & 1.3 & 33.4 & 0.9 & $37 \cdot 2$ & 0.8 & 41.6 & 0.9 & $48 \cdot 3$ & 1.6 & $<0.0001$ & $<0.0001$ \\
\hline $\begin{array}{l}\text { Income } \\
\quad\left(10^{4} \mathrm{KRW}\right) \ddagger\end{array}$ & $139 \cdot 9$ & 3.4 & $231 \cdot 0$ & $6 \cdot 5$ & 233.9 & 4.9 & $307 \cdot 0$ & $8 \cdot 2$ & $442 \cdot 3$ & $16 \cdot 1$ & $398 \cdot 1$ & $6 \cdot 7$ & $443 \cdot 2$ & $13 \cdot 3$ & $<0.0001$ & $<0.0001$ \\
\hline Women & \multicolumn{2}{|c|}{4021} & \multicolumn{2}{|c|}{3839} & \multicolumn{2}{|c|}{3608} & \multicolumn{2}{|c|}{9595} & \multicolumn{2}{|c|}{10265} & \multicolumn{2}{|c|}{9357} & \multicolumn{2}{|c|}{3190} & & \\
\hline Age (years) & $42 \cdot 3$ & 0.4 & $42 \cdot 8$ & 0.4 & $44 \cdot 3$ & 0.3 & $45 \cdot 6$ & 0.3 & $46 \cdot 5$ & 0.3 & $47 \cdot 4$ & 0.3 & $48 \cdot 0$ & 0.5 & $<0.0001$ & $<0.0001$ \\
\hline $19-29$ & 25.9 & 0.9 & $24 \cdot 7$ & 0.9 & 21.3 & 0.9 & $19 \cdot 6$ & 0.7 & $18 \cdot 3$ & 0.6 & $17 \cdot 1$ & 0.6 & $16 \cdot 7$ & 1.0 & $<0.0001$ & 0.0064 \\
\hline $30-49$ & $43 \cdot 9$ & $1 \cdot 2$ & 44.5 & 1.0 & $44 \cdot 8$ & $1 \cdot 1$ & 43.0 & 0.8 & $41 \cdot 1$ & 0.7 & 38.9 & 0.7 & $37 \cdot 8$ & $1 \cdot 2$ & $<0.0001$ & $<0.0001$ \\
\hline $50-64$ & $18 \cdot 4$ & 0.8 & $18 \cdot 3$ & 0.7 & $19 \cdot 6$ & 0.7 & $21 \cdot 6$ & 0.5 & 23.8 & 0.5 & $25 \cdot 8$ & 0.5 & $26 \cdot 9$ & 1.0 & $<0.0001$ & $<0.0001$ \\
\hline$\geq 65$ & 11.8 & 0.7 & $12 \cdot 5$ & 0.7 & $14 \cdot 3$ & 0.7 & $15 \cdot 8$ & 0.5 & $16 \cdot 8$ & 0.5 & $18 \cdot 2$ & 0.5 & $18 \cdot 6$ & 1.0 & $<0.0001$ & 0.0038 \\
\hline \multicolumn{17}{|l|}{ Education† } \\
\hline$\leq$ Middle school & 44.8 & 1.0 & 39.4 & 0.9 & $34 \cdot 2$ & 0.8 & $32 \cdot 0$ & 0.5 & 28.5 & 0.5 & $23 \cdot 6$ & 0.4 & $21 \cdot 7$ & 0.7 & $<0.0001$ & $<0.0001$ \\
\hline High school & 35.4 & 0.9 & $37 \cdot 1$ & 0.9 & $35 \cdot 8$ & 1.0 & $40 \cdot 8$ & 0.7 & 38.7 & 0.8 & $37 \cdot 7$ & 0.7 & 37.5 & 1.3 & 0.0003 & 0.2567 \\
\hline$\geq$ College & $19 \cdot 8$ & $1 \cdot 1$ & 23.5 & 0.9 & $30 \cdot 1$ & $1 \cdot 1$ & $27 \cdot 1$ & 0.7 & $32 \cdot 8$ & 0.8 & 38.7 & 0.8 & $40 \cdot 9$ & $1 \cdot 3$ & $<0.0001$ & $<0.0001$ \\
\hline $\begin{array}{l}\text { Income } \\
\left(10^{4} \mathrm{KRW}\right) \ddagger\end{array}$ & $140 \cdot 8$ & 3.5 & $231 \cdot 0$ & $6 \cdot 4$ & 235.4 & $5 \cdot 4$ & $313 \cdot 3$ & 11.4 & $457 \cdot 8$ & $15 \cdot 1$ & $391 \cdot 1$ & $6 \cdot 4$ & $443 \cdot 0$ & $12 \cdot 7$ & $<0.0001$ & $<0.0001$ \\
\hline
\end{tabular}

KRW, Korean won (approximately $1120 \mathrm{KRW}$ equal to 1 US dollar).

${ }^{*} P$ for trend by multivariate linear regression or logistic regression.

†Age-standardized based on the 2005 Korea census.

fHousehold monthly income with age standardized.

fermented foods and kimchi consumption declined significantly over time.

In contrast, pickled vegetable consumption and $\mathrm{Na}$ intake from pickled vegetables increased over time. Specifically, consumption of pickled vegetables was highest in young adults aged $19-29$ years $(8.2$ to $15.7 \mathrm{~g}$ in men and 6.1 to $9.7 \mathrm{~g}$ in women), and lowest in the elderly aged $\geq 65$ years ( 1.3 to $5.6 \mathrm{~g}$ in men and 0.9 to $3.7 \mathrm{~g}$ in women). It appears that young adults, especially those aged 19-29 years, prefer to consume pickled vegetables instead of kimchi. In contrast, the elderly seem to prefer the traditional kimchi.

In Korea, fermented red pepper paste, fermented soyabean paste and soya sauce are usually consumed as a condiment or sauce, or added to soups or stews. Intake of fermented red pepper paste increased significantly over time (by approximately $47.1 \%$ in men and $39.4 \%$ in women); however, fermented soyabean paste intake diminished greatly (by approximately $13.1 \%$ in men and $18.8 \%$ in women). One reason might be that spicy foods have been gaining in popularity and food companies have increased development of different types of spicy foods that have been a great success in Korea, and globally as well. Fermented red pepper paste may be utilized as a condiment for foods or as an addition to soups or stews, rather than the traditional fermented soyabean paste.

Yet, no dramatic changes were observed in the trends for soya sauce intake and Na consumption from soya sauce over time. Soya sauce has been a consistent part of the Korean diet as it is incorporated in a wide variety of foods and recipes. However, Na intake from soya sauce from 2007-2009 to 2016 decreased significantly in men, by approximately $10 \%$.

A plausible reason for decreases in fermented food intakes over time could be related to changes in overall dietary patterns in Korea. From the 1970s, dramatic economic and sociodemographic changes have occurred ${ }^{(18)}$. For example, the household monthly income in Korea has increased significantly, more than three times from 1998 to 2016 (Table 1). With greater exposure to the world, the diet in Korea has shifted to becoming more Westernized, particularly with convenience foods. An example for grains is ramen: it contributed the highest percentage of $\mathrm{Na}$ consumption, $33 \cdot 1-56 \cdot 6 \%$ in men and $25 \cdot 1-42 \cdot 3 \%$ in women from 1998 to $2010^{(19)}$. This changing pattern of foods also could be associated with increased dining out, as well as advancing age, income and educational level ${ }^{(20)}$. Those who ate outside the home $\geq 1$ 
Table 2 Trends in age-standardized fermented food intake for Korean adults, aged $\geq 19$ years, from the 1998 to 2016 Korea National Health and Nutrition Examination Surveys (KNHANES)

\begin{tabular}{|c|c|c|c|c|c|c|c|c|c|c|c|c|c|c|c|c|}
\hline & \multicolumn{16}{|c|}{ KNHANES } \\
\hline & \multicolumn{2}{|c|}{$\begin{array}{c}\mathrm{I} \\
(1998)\end{array}$} & \multicolumn{2}{|c|}{$\begin{array}{c}\text { II } \\
(2001)\end{array}$} & \multicolumn{2}{|c|}{$\begin{array}{c}\text { III } \\
(2005)\end{array}$} & \multicolumn{2}{|c|}{$\begin{array}{c}\text { IV } \\
(2007-2009)\end{array}$} & \multicolumn{2}{|c|}{$\begin{array}{c}\mathrm{V} \\
(2010-2012)\end{array}$} & \multicolumn{2}{|c|}{$\begin{array}{c}\text { VI } \\
(2013-2015) \\
\end{array}$} & \multicolumn{2}{|c|}{$\begin{array}{c}\text { VII } \\
(2016)\end{array}$} & \multicolumn{2}{|c|}{$P$ for trend ${ }^{*}$} \\
\hline & $\begin{array}{c}n \\
\text { or } \\
\text { mean }\end{array}$ & SE & $\begin{array}{c}n \\
\text { or } \\
\text { mean }\end{array}$ & SE & $\begin{array}{c}n \\
\text { or } \\
\text { mean }\end{array}$ & SE & $\begin{array}{c}n \\
\text { or } \\
\text { mean }\end{array}$ & SE & $\begin{array}{c}n \\
\text { or } \\
\text { mean }\end{array}$ & SE & $\begin{array}{c}n \\
\text { or } \\
\text { mean }\end{array}$ & SE & $\begin{array}{c}n \\
\text { or } \\
\text { mean }\end{array}$ & SE & $\begin{array}{l}1998 \text { to } \\
2016\end{array}$ & $\begin{array}{l}2007- \\
2009 \text { to } \\
2016\end{array}$ \\
\hline Men & \multicolumn{2}{|c|}{3480} & \multicolumn{2}{|c|}{3253} & \multicolumn{2}{|c|}{2918} & \multicolumn{2}{|c|}{6592} & \multicolumn{2}{|c|}{7129} & \multicolumn{2}{|l|}{6712} & \multicolumn{2}{|c|}{2240} & & \\
\hline Kimchi & 163.9 & 3.7 & $168 \cdot 4$ & 3.5 & $162 \cdot 3$ & 3.0 & $152 \cdot 1$ & $2 \cdot 2$ & $140 \cdot 0$ & $2 \cdot 3$ & $126 \cdot 8$ & $2 \cdot 1$ & $118 \cdot 4$ & 3.0 & $<0.0001$ & $<0.0001$ \\
\hline $\begin{array}{l}\text { Fermented red } \\
\text { pepper paste }\end{array}$ & $5 \cdot 1$ & 0.3 & $6 \cdot 3$ & 0.3 & 8.4 & 0.4 & 8.0 & $0 . \overline{3}$ & 8.4 & 0.3 & 8.3 & 0.2 & 7.5 & 0.4 & $<0.0001$ & 0.3958 \\
\hline $\begin{array}{l}\text { Fermented soyabean } \\
\text { paste }\end{array}$ & $10 \cdot 7$ & 0.4 & 14.5 & 0.6 & $14 \cdot 8$ & 0.5 & $13 \cdot 3$ & 0.3 & $12 \cdot 4$ & 0.3 & $10 \cdot 1$ & 0.3 & $9 \cdot 3$ & 0.4 & $<0.0001$ & $<0.0001$ \\
\hline Soya sauce & $7 \cdot 7$ & 0.3 & $7 \cdot 4$ & 0.2 & $9 \cdot 4$ & 0.3 & $8 \cdot 4$ & 0.2 & $8 \cdot 3$ & 0.2 & $8 \cdot 0$ & 0.2 & $8 \cdot 0$ & 0.3 & 0.4554 & 0.0727 \\
\hline $\begin{array}{l}\text { Salt-fermented } \\
\text { seafood }\end{array}$ & $3 \cdot 7$ & 0.3 & $3 \cdot 2$ & 0.3 & $2 \cdot 4$ & 0.2 & $2 \cdot 6$ & $0 \cdot 2$ & $2 \cdot 5$ & 0.2 & 1.5 & $0 \cdot 1$ & $1 \cdot 6$ & 0.1 & $<0.0001$ & $<0.0001$ \\
\hline Pickled vegetables & $5 \cdot 1$ & 0.4 & 7.3 & 0.7 & 7.8 & 0.4 & $8 \cdot 0$ & 0.3 & $10 \cdot 3$ & 0.4 & $10 \cdot 1$ & 0.4 & $10 \cdot 6$ & 0.6 & $<0.0001$ & 0.0002 \\
\hline Total & $196 \cdot 2$ & 3.8 & $207 \cdot 0$ & 3.8 & $205 \cdot 1$ & $3 \cdot 1$ & 192.4 & $2 \cdot 3$ & 181.9 & $2 \cdot 4$ & $164 \cdot 7$ & $2 \cdot 2$ & 155.4 & 3.2 & $<0.0001$ & $<0.0001$ \\
\hline Women & \multicolumn{2}{|c|}{4021} & \multicolumn{2}{|c|}{3839} & \multicolumn{2}{|c|}{3608} & 9595 & & \multicolumn{2}{|c|}{10265} & 9357 & & \multicolumn{2}{|c|}{3190} & & \\
\hline \multicolumn{17}{|c|}{ Fermented food intake $(\mathrm{g})$} \\
\hline Kimchi & $129 \cdot 2$ & $2 \cdot 7$ & 139.2 & $2 \cdot 8$ & $120 \cdot 4$ & $2 \cdot 0$ & $108 \cdot 3$ & 1.6 & 92.5 & 1.4 & $84 \cdot 2$ & 1.5 & $79 \cdot 8$ & $2 \cdot 1$ & $<0.0001$ & $<0.0001$ \\
\hline $\begin{array}{l}\text { Fermented red } \\
\text { pepper paste }\end{array}$ & $3 \cdot 3$ & 0.2 & 3.8 & 0.2 & $6 \cdot 1$ & 0.2 & 4.6 & 0.2 & $4 \cdot 7$ & 0.2 & $5 \cdot 3$ & 0.2 & $4 \cdot 6$ & 0.3 & $<0.0001$ & 0.1778 \\
\hline $\begin{array}{l}\text { Fermented soyabean } \\
\text { paste }\end{array}$ & $8 \cdot 0$ & 0.3 & $12 \cdot 2$ & 0.5 & 11.5 & 0.4 & 8.9 & 0.2 & $8 \cdot 1$ & 0.2 & $6 \cdot 5$ & 0.2 & $6 \cdot 5$ & 0.3 & $<0.0001$ & $<0.0001$ \\
\hline Soya sauce & $6 \cdot 3$ & 0.3 & $6 \cdot 0$ & 0.2 & $7 \cdot 4$ & 0.2 & $5 \cdot 6$ & 0.1 & $6 \cdot 1$ & 0.1 & $6 \cdot 0$ & 0.1 & $5 \cdot 7$ & 0.2 & 0.0048 & 0.7900 \\
\hline $\begin{array}{l}\text { Salt-fermented } \\
\text { seafood }\end{array}$ & $2 \cdot 8$ & 0.2 & $2 \cdot 1$ & 0.2 & $2 \cdot 1$ & 0.2 & $1 \cdot 3$ & 0.1 & $1 \cdot 2$ & 0.1 & $1 \cdot 0$ & 0.1 & $1 \cdot 0$ & 0.1 & $<0.0001$ & 0.0009 \\
\hline Pickled vegetables & 3.3 & 0.3 & 5.9 & 0.4 & $5 \cdot 8$ & 0.3 & 6.7 & 0.2 & 8.1 & 0.3 & 8.1 & 0.3 & 7.9 & 0.4 & $<0.0001$ & 0.0256 \\
\hline Total & $152 \cdot 8$ & $2 \cdot 8$ & $169 \cdot 1$ & 3.0 & $153 \cdot 3$ & $2 \cdot 1$ & 135.5 & 1.6 & $120 \cdot 7$ & 1.5 & $111 \cdot 1$ & 1.5 & $105 \cdot 5$ & $2 \cdot 1$ & $<0.0001$ & $<0.0001$ \\
\hline
\end{tabular}

${ }^{*} P$ for trend by multivariate linear regression, adjusting for age.

(a)

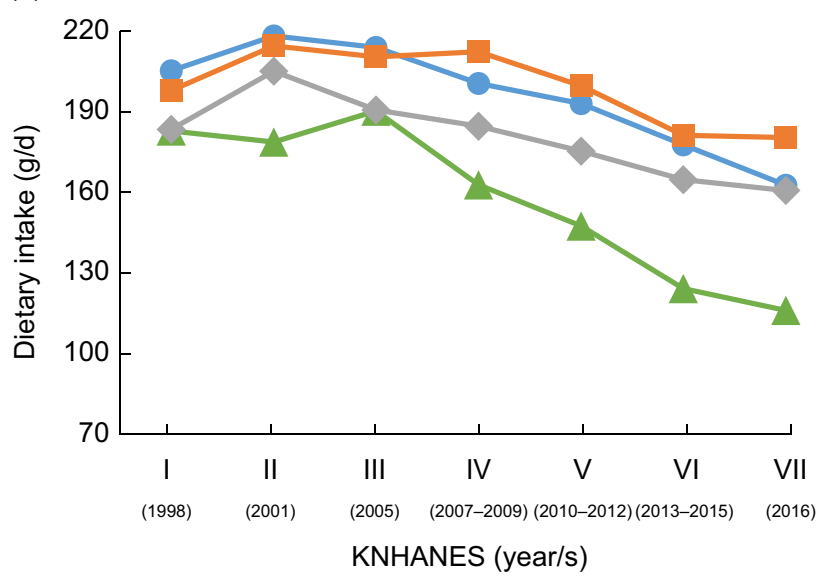

(b)

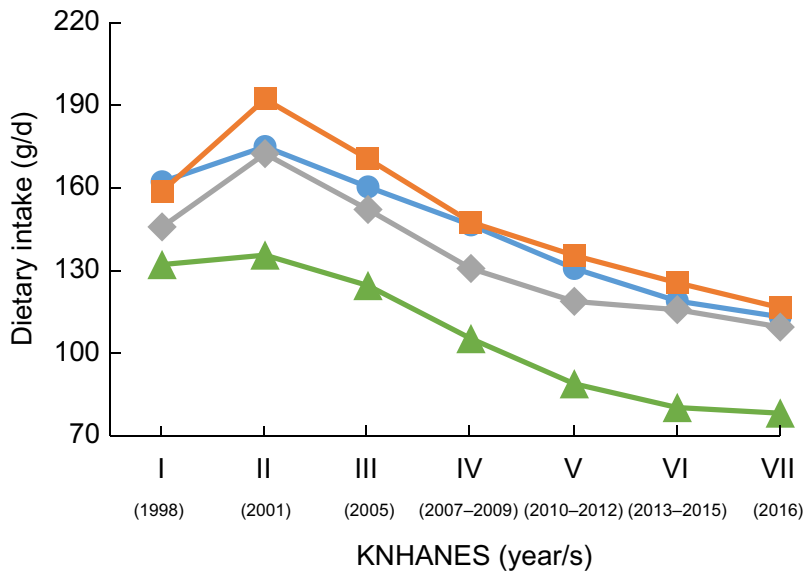

Fig. 1 (colour online) Trends in total fermented food intake of Korean adults by sex (a, men; b, women) and age category ( $₫$, 19-29 years; $-\rightarrow, 30-49$ years; --, 50-64 years; $\rightarrow-, \geq 65$ years) from 1998 to 2016 , Korea National Health and Nutrition Examination Survey (KNHANES)

times per day were $44.3 \%$ among men and $23 \cdot 2 \%$ among women in 2016, and even higher in the younger age group of $19-29$ years $(51 \cdot 1 \% \text { in men and } 34.1 \% \text { in women })^{(6)}$. Other reasons might be changing taste preferences with exposure to international foods, and a lack of time or desire for greater convenience ${ }^{(21)}$. Young adults may have developed their food choices and habits from early childhood, as the traditional Korean diet has declined with greater intake of Western-style foods. These foods include flour products such as bread; and pizza and hamburgers, particularly among 


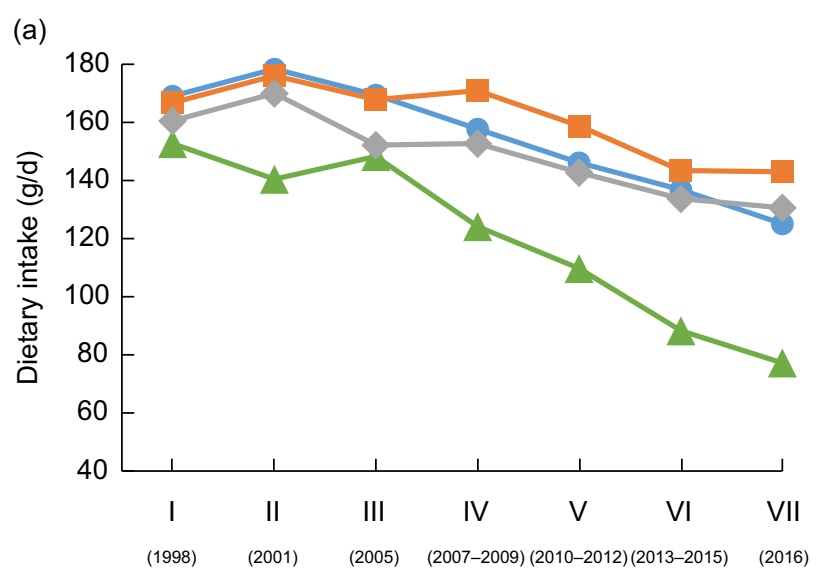

KNHANES (year/s) (b)

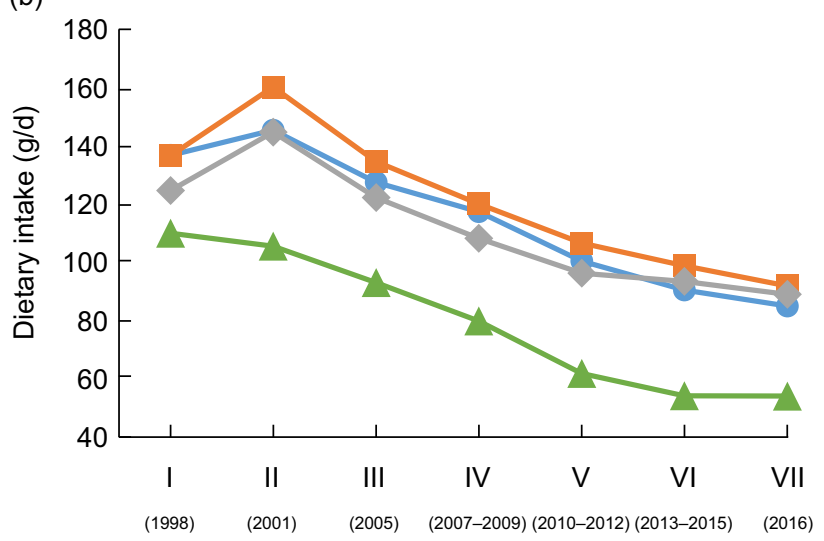

KNHANES (year/s)

Fig. 2 (colour online) Trends in kimchi intake of Korean adults by sex (a, men; b, women) and age category ( - , 19-29 years; -- , 30-49 years;,-- 50-64 years; $\rightarrow-, \geq 65$ years) from 1998 to 2016, Korea National Health and Nutrition Examination Survey (KNHANES)

(a)

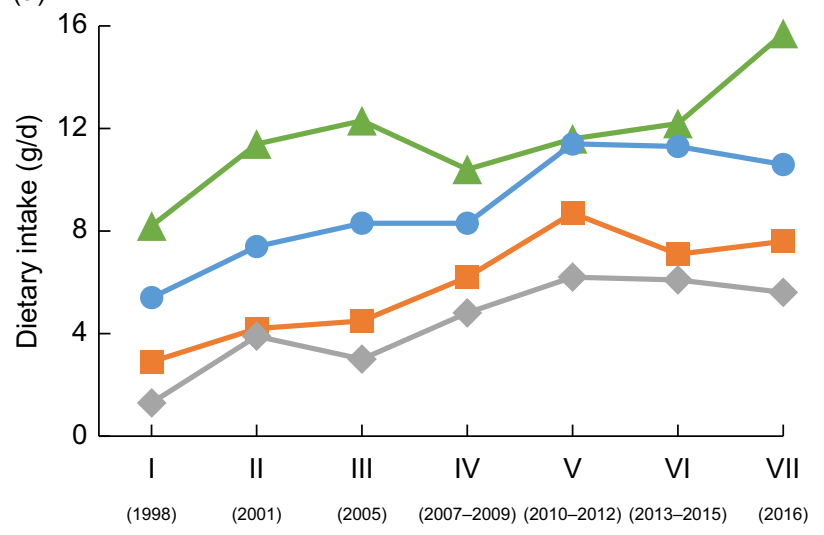

KNHANES (year/s) (b)

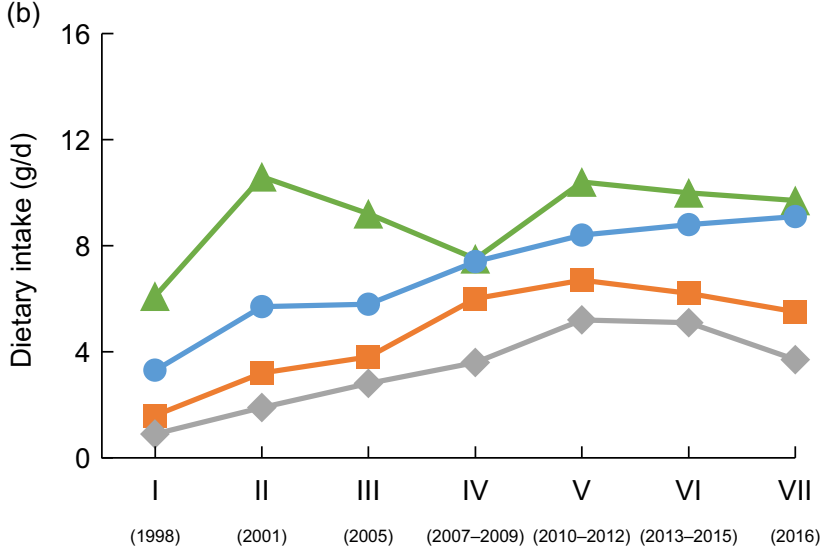

KNHANES (year/s)

Fig. 3 (colour online) Trends in pickled vegetable intake of Korean adults by sex (a, men; b, women) and age category (,$-- 19-29$ years; $-\rightarrow, 30-49$ years;,$-- 50-64$ years; $\rightarrow-, \geq 65$ years) from 1998 to 2016 , Korea National Health and Nutrition Examination Survey (KNHANES)

Korean adolescents ${ }^{(22)}$. Furthermore, the food delivery system has become more established and prevalent in Korea. It is common for people to order fast foods such as fried chicken, pizza or noodles to be delivered, rather than consuming a traditional home-cooked meal. Finally, restaurants and take-out establishments generally serve foods accompanied by pickled vegetables such as pickled cucumbers, pickled radish or pickled yellow radish. The presence of these extra side dishes presumably leads to an increased consumption of these fermented foods.

The goal of $\mathrm{Na}$ intake for Korean adults is $2000 \mathrm{mg} / \mathrm{d}$ according to the Dietary Reference Intakes for Koreans and the $\mathrm{WHO}^{(11,23)}$. This level is higher than the daily $1500 \mathrm{mg}$ recommended in the USA for adults aged 19-50 years (1300 $\mathrm{mg}$ for $51-70$ years and $1200 \mathrm{mg}$ for $>70$ years). Yet, it is lower than the US tolerable upper intake of $2300 \mathrm{mg} / \mathrm{d}^{(24)}$. Nevertheless, the overall $\mathrm{Na}$ consumption by Koreans is still greater than that of their guidelines. A study by Lee et $a l$. reported that the contribution of dietary $\mathrm{Na}$ was highest from foods such as kimchi, soya sauce, soyabean paste and ramen, based on the 1998, 2005 and 2007-2009 KNHANES ${ }^{(25)}$. Specifically, kimchi is the most popular type of fermented food in Korea and it contributes the highest proportion of $\mathrm{Na}$ to the daily diet, $22 \cdot 8-31.7 \%$, according to the 1998 and 2010 KNHANES $^{(19)}$. Fermented foods are well known to contain a high amount of $\mathrm{Na}$. However, the trend analysis of the present paper reported a significant decrease in both fermented food consumption and $\mathrm{Na}$ intake from fermented foods overall for Korean adults, both men and women, from 1998 to 2016. One of the most important results noted was that total daily $\mathrm{Na}$ intake from overall diet decreased noticeably over time, with a decline of approximately $15 \%$ in men and $28 \%$ in women between 1998 and 2016. In addition, this decrease 


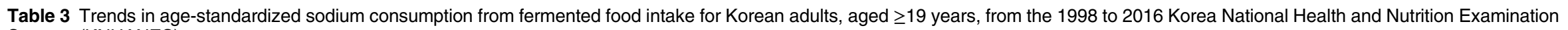
Surveys (KNHANES)

\begin{tabular}{|c|c|c|c|c|c|c|c|c|c|c|c|c|c|c|c|c|}
\hline & \multicolumn{16}{|c|}{ KNHANES } \\
\hline & \multicolumn{2}{|c|}{$\begin{array}{c}1 \\
(1998) \\
\end{array}$} & \multicolumn{2}{|c|}{$\begin{array}{c}\text { II } \\
(2001) \\
\end{array}$} & \multicolumn{2}{|c|}{$\begin{array}{c}\text { III } \\
(2005)\end{array}$} & \multicolumn{2}{|c|}{$\begin{array}{c}\text { IV } \\
(2007-2009)\end{array}$} & \multicolumn{2}{|c|}{$\begin{array}{c}\mathrm{V} \\
(2010-2012)\end{array}$} & \multicolumn{2}{|c|}{$\begin{array}{c}\text { VI } \\
(2013-2015)\end{array}$} & \multicolumn{2}{|c|}{$\begin{array}{c}\text { VII } \\
(2016)\end{array}$} & \multicolumn{2}{|c|}{$P$ for trend ${ }^{*}$} \\
\hline & $\begin{array}{l}n \text { or } \\
\text { mean }\end{array}$ & SE & $\begin{array}{l}n \text { or } \\
\text { mean }\end{array}$ & SE & $\begin{array}{l}n \text { or } \\
\text { mean }\end{array}$ & SE & $\begin{array}{l}n \text { or } \\
\text { mean }\end{array}$ & SE & $\begin{array}{c}n \text { or } \\
\text { mean }\end{array}$ & SE & $\begin{array}{l}n \text { or } \\
\text { mean }\end{array}$ & SE & $\begin{array}{l}n \text { or } \\
\text { mean }\end{array}$ & SE & $\begin{array}{c}1998 \\
\text { to } 2016\end{array}$ & $\begin{array}{c}2007- \\
2009 \text { to } \\
2016\end{array}$ \\
\hline Men & \multicolumn{2}{|c|}{3480} & \multicolumn{2}{|c|}{3253} & \multicolumn{2}{|c|}{2918} & \multicolumn{2}{|c|}{6592} & \multicolumn{2}{|c|}{7129} & \multicolumn{2}{|c|}{6712} & \multicolumn{2}{|c|}{2240} & & \\
\hline $\begin{array}{l}\text { Daily Na intake (mg) } \\
\mathrm{Na} \text { intake (mg) }\end{array}$ & $5562 \cdot 1$ & $86 \cdot 0$ & $6019 \cdot 4$ & $80 \cdot 3$ & $6400 \cdot 6$ & 81.5 & $5905 \cdot 5$ & $50 \cdot 9$ & $6030 \cdot 1$ & $60 \cdot 4$ & $4858 \cdot 3$ & $54 \cdot 7$ & $4704 \cdot 8$ & $79 \cdot 7$ & $<0.0001$ & $<0.0001$ \\
\hline Kimchi & $1992 \cdot 4$ & $47 \cdot 7$ & $1995 \cdot 7$ & $46 \cdot 0$ & $1806 \cdot 4$ & $35 \cdot 3$ & 1693.7 & $27 \cdot 8$ & $1569 \cdot 1$ & $30 \cdot 9$ & 785.8 & $13 \cdot 2$ & $730 \cdot 6$ & $18 \cdot 7$ & $<0.0001$ & $<0.0001$ \\
\hline Fermented red pepper paste & $126 \cdot 3$ & $6 \cdot 1$ & $203 \cdot 1$ & 9.8 & 273.0 & 13.9 & $260 \cdot 0$ & $8 \cdot 2$ & $274 \cdot 1$ & 8.4 & $213 \cdot 1$ & $6 \cdot 1$ & $195 \cdot 1$ & $11 \cdot 6$ & $<0.0001$ & $<0.0001$ \\
\hline Fermented soyabean paste & 442.5 & $17 \cdot 6$ & 594.4 & 24.5 & $568 \cdot 3$ & $17 \cdot 7$ & $570 \cdot 5$ & $13 \cdot 1$ & $559 \cdot 7$ & $15 \cdot 4$ & $410 \cdot 9$ & 11.5 & 374.0 & $16 \cdot 5$ & $<0.0001$ & $<0.0001$ \\
\hline Soya sauce & 478.0 & $16 \cdot 5$ & $456 \cdot 8$ & 14.6 & 582.7 & $17 \cdot 0$ & $519 \cdot 1$ & $10 \cdot 6$ & 505.8 & 10.5 & 471.9 & $13 \cdot 0$ & 468.5 & $17 \cdot 0$ & 0.3754 & 0.0009 \\
\hline Salt-fermented seafood & $163 \cdot 1$ & $12 \cdot 9$ & 145.9 & $18 \cdot 2$ & $106 \cdot 4$ & 9.0 & 111.1 & $6 \cdot 8$ & $115 \cdot 9$ & 7.5 & 77.9 & 4.1 & 76.0 & $6 \cdot 1$ & $<0.0001$ & $<0.0001$ \\
\hline Pickled vegetables & $61 \cdot 7$ & 4.7 & 94.2 & $7 \cdot 7$ & $101 \cdot 0$ & $5 \cdot 6$ & $106 \cdot 4$ & $4 \cdot 2$ & 135.9 & $5 \cdot 3$ & $134 \cdot 2$ & 5.4 & $130 \cdot 9$ & 8.0 & $<0.0001$ & 0.0091 \\
\hline Total fermented foods & $3264 \cdot 0$ & 60.6 & $3490 \cdot 0$ & 64.8 & 3437.8 & $50 \cdot 0$ & $3260 \cdot 7$ & $36 \cdot 6$ & $3160 \cdot 5$ & $40 \cdot 9$ & $2093 \cdot 7$ & 25.5 & $1975 \cdot 0$ & $37 \cdot 0$ & $<0.0001$ & $<0.0001$ \\
\hline Women & \multicolumn{2}{|c|}{4021} & \multicolumn{2}{|c|}{3839} & \multicolumn{2}{|c|}{3608} & \multicolumn{2}{|c|}{9595} & \multicolumn{2}{|c|}{10265} & \multicolumn{2}{|c|}{9357} & \multicolumn{2}{|c|}{3190} & & \\
\hline $\begin{array}{l}\text { Daily Na intake (mg) } \\
\text { Na intake (mg) }\end{array}$ & 4387.3 & 69.9 & 4936.5 & 73.0 & $4971 \cdot 2$ & $60 \cdot 6$ & $4106 \cdot 9$ & 35.6 & $4219 \cdot 0$ & $39 \cdot 2$ & $3386 \cdot 7$ & 30.6 & 3171.6 & $50 \cdot 3$ & $<0.0001$ & $<0.0001$ \\
\hline Kimchi & 1607.9 & $36 \cdot 7$ & $1720 \cdot 7$ & $40 \cdot 3$ & $1378 \cdot 2$ & $23 \cdot 9$ & $1226 \cdot 1$ & $20 \cdot 9$ & $1054 \cdot 3$ & 20.5 & 518.9 & $9 \cdot 0$ & $492 \cdot 0$ & $13 \cdot 1$ & $<0.0001$ & $<0.0001$ \\
\hline Fermented red pepper paste & $80 \cdot 2$ & 3.7 & 121.5 & $6 \cdot 6$ & $196 \cdot 8$ & $7 \cdot 2$ & $150 \cdot 6$ & 4.9 & $154 \cdot 1$ & $5 \cdot 0$ & $136 \cdot 8$ & $4 \cdot 1$ & $120 \cdot 5$ & 6.7 & $<0.0001$ & 0.0001 \\
\hline Fermented soyabean paste & 333.5 & 13.9 & 514.0 & $22 \cdot 0$ & $436 \cdot 3$ & $14 \cdot 3$ & 372.5 & $10 \cdot 3$ & 372.5 & $9 \cdot 4$ & 264.8 & $6 \cdot 6$ & 254.8 & 9.9 & $<0.0001$ & $<0.0001$ \\
\hline Soya sauce & $395 \cdot 0$ & $15 \cdot 6$ & 368.6 & $14 \cdot 4$ & $459 \cdot 3$ & $13 \cdot 0$ & 347.9 & $7 \cdot 3$ & 373.9 & $8 \cdot 1$ & 354.3 & $7 \cdot 3$ & 332.3 & $10 \cdot 7$ & $<0.0001$ & 0.1582 \\
\hline Salt-fermented seafood & $113 \cdot 7$ & 9.0 & 105.4 & $9 \cdot 6$ & $100 \cdot 0$ & 9.0 & $67 \cdot 0$ & 4.9 & 67.5 & 3.4 & $55 \cdot 4$ & 3.5 & $47 \cdot 8$ & 3.6 & $<0.0001$ & 0.0005 \\
\hline Pickled vegetables & $42 \cdot 6$ & 3.6 & 77.5 & $5 \cdot 1$ & $75 \cdot 0$ & 4.3 & $91 \cdot 2$ & 3.4 & $109 \cdot 1$ & 3.8 & $117 \cdot 8$ & $5 \cdot 0$ & 104.5 & 7.0 & $<0.0001$ & 0.0355 \\
\hline Total fermented foods & 2572.9 & $47 \cdot 2$ & $2907 \cdot 6$ & 54.5 & 2645.5 & 33.5 & 2255.4 & $26 \cdot 2$ & $2131 \cdot 3$ & $24 \cdot 8$ & 1447.9 & $15 \cdot 7$ & 1351.8 & 23.1 & $<0.0001$ & $<0.0001$ \\
\hline
\end{tabular}

${ }^{*} P$ for trend by multivariate linear regression, adjusting for age. 
Table 4 Trend in percentage contribution of sodium intake from fermented foods to total daily sodium intake for Korean adults, aged $\geq 19$ years, from the 1998 to 2016 Korea National Health and Nutrition Examination Surveys (KNHANES)

\begin{tabular}{|c|c|c|c|c|c|c|c|c|c|c|c|c|c|c|c|c|}
\hline & \multicolumn{16}{|c|}{ KNHANES } \\
\hline & \multicolumn{2}{|c|}{$\begin{array}{c}\mathrm{I} \\
(1998)\end{array}$} & \multicolumn{2}{|c|}{$\begin{array}{c}\text { II } \\
(2001)\end{array}$} & \multicolumn{2}{|c|}{$\begin{array}{c}\text { III } \\
(2005)\end{array}$} & \multicolumn{2}{|c|}{$\begin{array}{c}\text { IV } \\
(2007-2009)\end{array}$} & \multicolumn{2}{|c|}{$\begin{array}{c}\mathrm{V} \\
(2010-2012)\end{array}$} & \multicolumn{2}{|c|}{$\begin{array}{c}\text { VI } \\
(2013-2015)\end{array}$} & \multicolumn{2}{|c|}{$\begin{array}{c}\text { VII } \\
(2016)\end{array}$} & \multicolumn{2}{|c|}{$P$ for trend ${ }^{*}$} \\
\hline & $\begin{array}{c}n \text { or } \\
\%\end{array}$ & SE & $\begin{array}{c}n \text { or } \\
\%\end{array}$ & SE & $\begin{array}{c}n \text { or } \\
\%\end{array}$ & SE & $\begin{array}{c}n \text { or } \\
\%\end{array}$ & SE & $\begin{array}{c}n \text { or } \\
\%\end{array}$ & SE & $\begin{array}{l}n \text { or } \\
\%\end{array}$ & SE & $\begin{array}{c}n \text { or } \\
\%\end{array}$ & SE & $\begin{array}{l}1998 \text { to } \\
2016\end{array}$ & $\begin{array}{l}2007- \\
2009 \text { to } \\
2016\end{array}$ \\
\hline Men & \multirow{2}{*}{\multicolumn{2}{|c|}{3466}} & \multirow{2}{*}{\multicolumn{2}{|c|}{3240}} & \multirow{2}{*}{\multicolumn{2}{|c|}{2903}} & \multirow{2}{*}{\multicolumn{2}{|c|}{6553}} & \multirow{2}{*}{\multicolumn{2}{|c|}{7094}} & \multirow{2}{*}{\multicolumn{2}{|c|}{6646}} & \multirow{2}{*}{\multicolumn{2}{|c|}{2214}} & & \\
\hline Na intake & & & & & & & & & & & & & & & & \\
\hline Kimchi & $35 \cdot 7$ & 0.6 & 33.3 & 0.5 & 29.2 & 0.4 & $29 \cdot 2$ & 0.5 & $26 \cdot 6$ & 0.4 & $19 \cdot 0$ & 0.4 & $17 \cdot 8$ & 0.4 & $<0.0001$ & $<0.0001$ \\
\hline $\begin{array}{l}\text { Fermented red } \\
\text { pepper paste }\end{array}$ & 2.5 & 0.1 & 3.6 & 0.2 & 4.2 & 0.2 & $4 \cdot 3$ & 0.1 & 4.5 & 0.2 & 4.4 & 0.1 & $4 \cdot 3$ & 0.1 & $<0.0001$ & 0.8111 \\
\hline $\begin{array}{l}\text { Fermented } \\
\quad \text { soyabean paste }\end{array}$ & $8 \cdot 3$ & 0.3 & $9 \cdot 7$ & 0.3 & $9 \cdot 1$ & 0.3 & $9 \cdot 5$ & 0.3 & 9.4 & 0.3 & $9 \cdot 1$ & 0.3 & $8 \cdot 8$ & 0.2 & 0.8820 & 0.0325 \\
\hline Soya sauce & $8 \cdot 7$ & 0.3 & $7 \cdot 7$ & 0.2 & $9 \cdot 2$ & 0.2 & 8.8 & 0.2 & $8 \cdot 6$ & 0.2 & $9 \cdot 8$ & 0.2 & $10 \cdot 1$ & 0.2 & $<0.0001$ & $<0.0001$ \\
\hline $\begin{array}{l}\text { Salt-fermented } \\
\text { seafood }\end{array}$ & $2 \cdot 4$ & 0.1 & $2 \cdot 0$ & 0.1 & 1.4 & $0 \cdot 1$ & 1.7 & $0 \cdot 1$ & $1 \cdot 7$ & $0 \cdot \overline{1}$ & 1.6 & 0.1 & $1 \cdot 6$ & 0.1 & $<0.0001$ & 0.4138 \\
\hline Pickled vegetables & $1 \cdot 2$ & 0.1 & 1.6 & 0.1 & 1.8 & 0.1 & 1.9 & 0.1 & $2 \cdot 4$ & 0.1 & $2 \cdot 8$ & 0.1 & $2 \cdot 8$ & 0.1 & $<0.0001$ & $<0.0001$ \\
\hline $\begin{array}{l}\text { Total fermented } \\
\text { foods }\end{array}$ & $58 \cdot 8$ & 0.5 & $57 \cdot 9$ & 0.5 & 54.9 & 0.5 & $55 \cdot 5$ & 0.5 & $53 \cdot 2$ & 0.5 & $46 \cdot 7$ & 0.1 & $45 \cdot 4$ & 0.3 & $<0.0001$ & $<0.0001$ \\
\hline $\begin{array}{l}\text { Women } \\
\text { Na intake }\end{array}$ & \multicolumn{2}{|c|}{3995} & \multicolumn{2}{|c|}{3799} & \multicolumn{2}{|c|}{3580} & \multicolumn{2}{|c|}{9500} & \multicolumn{2}{|c|}{10174} & \multicolumn{2}{|c|}{9231} & \multicolumn{2}{|c|}{3137} & & \\
\hline Kimchi & $36 \cdot 3$ & 0.6 & $34 \cdot 0$ & 0.5 & 28.7 & 0.4 & $29 \cdot 9$ & 0.3 & $25 \cdot 5$ & 0.3 & $18 \cdot 2$ & 0.5 & $18 \cdot 2$ & 0.4 & $<0.0001$ & $<0.0001$ \\
\hline $\begin{array}{l}\text { Fermented red } \\
\text { pepper paste }\end{array}$ & $2 \cdot 1$ & 0.1 & $2 \cdot 7$ & 0.1 & $4 \cdot 1$ & $0 \cdot 1$ & 3.7 & $0 \cdot 1$ & 3.8 & 0.1 & 4.0 & 0.2 & 3.9 & 0.2 & $<0.0001$ & 0.1730 \\
\hline $\begin{array}{l}\text { Fermented } \\
\text { soyabean paste }\end{array}$ & $8 \cdot 2$ & 0.3 & $10 \cdot 2$ & 0.3 & $9 \cdot 4$ & 0.3 & $9 \cdot 5$ & 0.2 & $9 \cdot 6$ & 0.2 & $9 \cdot 3$ & 0.3 & $9 \cdot 3$ & 0.3 & 0.5591 & 0.3750 \\
\hline Soya sauce & 9.5 & 0.3 & $7 \cdot 4$ & 0.2 & $9 \cdot 4$ & 0.2 & 8.6 & 0.2 & $9 \cdot 1$ & 0.2 & $10 \cdot 4$ & 0.3 & 11.0 & 0.3 & $<0.0001$ & $<0.0001$ \\
\hline $\begin{array}{l}\text { Salt-fermented } \\
\text { seafood }\end{array}$ & $2 \cdot 3$ & 0.2 & 1.9 & 0.1 & $1 \cdot 7$ & $0 \cdot 1$ & 1.5 & 0.1 & 1.5 & $0 \cdot 1$ & 1.6 & 0.1 & 1.5 & 0.1 & $<0.0001$ & 0.7415 \\
\hline Pickled vegetables & 1.1 & 0.1 & 1.7 & 0.1 & 1.6 & 0.1 & $2 \cdot 3$ & $0 \cdot 1$ & $2 \cdot 7$ & 0.1 & 3.3 & 0.2 & 3.2 & 0.2 & $<0.0001$ & $<0.0001$ \\
\hline $\begin{array}{l}\text { Total fermented } \\
\text { foods }\end{array}$ & 59.4 & 0.5 & 57.9 & 0.5 & $55 \cdot 0$ & 0.4 & 55.5 & 0.3 & $52 \cdot 2$ & 0.3 & $46 \cdot 8$ & 0.6 & $47 \cdot 0$ & 0.6 & $<0.0001$ & $<0.0001$ \\
\hline
\end{tabular}

${ }^{\star} P$ for trend by multivariate logistic regression.

could be attributed to greater awareness of the negative influence of excessive Na consumption in Korea ${ }^{(26)}$. One plausible reason for the awareness could be a campaign to promote eating less $\mathrm{Na}$ that was initiated by the Ministry of Food and Drug Safety in 2012. This campaign even resulted in numerous manufacturers producing low-Na products voluntarily ${ }^{(27)}$. Also, information on the negative impact of high $\mathrm{Na}$ intake has been presented in numerous types of media and literature throughout the years. For example, it has been reported that the incidence of osteoporosis and hypertension in Korea is related to high $\mathrm{Na}$ consumption for postmenopausal women ${ }^{(28)}$. Also, experts have elaborated on the importance of reducing dietary $\mathrm{Na}$ as decreased salt intake lowers blood pressure and this could be protective against end-organ damage from diabetes ${ }^{(29)}$. This message may have been effective. A Korean study by Kang et al. observed that those with diabetes consumed less $\mathrm{Na}(4910 \mathrm{mg})$ overall than those without the diabetes $(5188 \mathrm{mg})$. Also, women recently diagnosed with diabetes consumed more $\mathrm{Na}$ ( $4314 \mathrm{mg}$ ) than those previously diagnosed with diabetes $(3813 \mathrm{mg})^{(30)}$. Although the prevalence of hypertension did not change noticeably over time in Korea, hypertension awareness increased dramatically from 1998 to 2016, specifically from 19.7 to $64.9 \%$ in men and from 29.6 to $66.8 \%$ in women ${ }^{(6)}$. This increased awareness might have been an influence on the decline in $\mathrm{Na}$ consumption over time, which may be related to hypertension.

A meta-analysis by Kim et al. showed that greater fresh vegetable intake was inversely related with the risk of gastric cancer. However, the risk of gastric cancer was increased with the consumption of processed vegetables such as pickling or adding salt ${ }^{(31)}$. Yet, the incidence rate of stomach cancer decreased from $43.6 \%$ in 1999 to $33.8 \%$ in 2015 in Korea $^{(32)}$. It is plausible that the significant trend for decreased fermented foods over time could be related to the concomitant declining risk in gastric cancer.

A strength of the present research is that existing KNHANES data from 1998 to 2016 were utilized for the trend analysis. It is the first to examine trends in fermented food intake, specifically six categories which represent the significant types of fermented foods in Korea, and trends in $\mathrm{Na}$ consumption from each fermented food over time with a representative Korean population. Estimation of $\mathrm{Na}$ consumption of individuals via a $24 \mathrm{~h}$ dietary recall is a challenge since the precise amount of $\mathrm{Na}$ in cooked dishes is 
difficult to define. However, KNHANES provides the most accurate examination of the Korean population at this time ${ }^{(33,34)}$. This trend analysis is important information for health professionals, as fermented foods remain the most popular side dishes of Korean meals. The data suggest that individuals should reduce $\mathrm{Na}$ intake and that health professionals should continue to provide education on the effects of $\mathrm{Na}$ intake related to health. Yet, a number of limitations exist. Methods used to collect samples changed from triennially to annually between 1998 to 2005 and 2007-2009 to 2016. Thus, $P$ for trend tests were performed separately for 1998 to 2016 and 2007-2009 to 2016 in the tables due to this reason. Also, the 24 h dietary recall method utilized does not capture habitual intake because individuals do not consume the same foods every day. In addition, this trend analysis was not focused on finding associations between fermented food intake and disease, but solely on identifying consumption trends. Therefore, variables such as weight and total energy intake were not adjusted for in the multivariate model. Further research could be undertaken to examine trends in $\mathrm{K}$ intake from fermented foods over time to determine if a close relationship with $\mathrm{Na}$ exists.

\section{Conclusion}

Consumption of fermented foods, especially kimchi, by Korean adults decreased significantly over time from 1998 to 2016. Also, Na intake overall, and $\mathrm{Na}$ intake per day, from total fermented foods was considerably reduced. Although pickled vegetable intake and $\mathrm{Na}$ intake from pickled vegetables increased noticeably over time, these condiments contribute only a small portion of the Korean diet. The downward trends in $\mathrm{Na}$ consumption overall are positive; however, a reduction in the addition of $\mathrm{Na}$ to fermented foods during the manufacturing process could help further lower total $\mathrm{Na}$ intake. The present research on trends in food consumption can help to identify the influence of fermented foods on potential health and help guide the development of future dietary recommendations in Korea.

\section{Acknowledgements}

Financial support: This research received no specific grant from any funding agency in the public, commercial or notfor-profit sectors. Conflict of interest: No potential conflict of interest was reported by the authors. Authorship: All authors contributed to the design and implementation of the research. J.H.F.-G. supervised the work overall, and S.Y.K. and H.J.K. analysed the data. Also, S.Y.K. and J.H.F.-G. Co-authored the manuscript. All authors discussed the results and reviewed and commented on subsequent drafts of the manuscript. All authors provided critical feedback and helped shape the research. Ethics of buman subject participation: Not applicable; this research was a secondary data analysis.

\section{References}

1. Chilton SN, Burton JP \& Reid G (2015) Inclusion of fermented foods in food guides around the world. Nutrients 7, 390-404.

2. Shin DH \& Jeong DY (2015) Korean traditional fermented soybean products: jang. J Ethn Foods 2, 2-7.

3. Kim J, Kang M, Lee JS et al. (2011) Fermented and nonfermented soy food consumption and gastric cancer in Japanese and Korean populations: a meta-analysis of observational studies. Cancer Sci 102, 231-244.

4. Du S, Neiman A, Batis C et al. (2014) Understanding the patterns and trends of sodium intake, potassium intake, and sodium to potassium ratio and their effect on hypertension in China. Am J Clin Nutr 99, 334-343.

5. Karppanen H \& Mervaala E (2006) Sodium intake and hypertension. Prog Cardiovasc Dis 49, 59-75.

6. Korea Centers for Disease Control and Prevention (2018) Korea Health Statistics 2016. Sejong City: Ministry of Health and Welfare, Republic of Korea.

7. Ong KL, Cheung BM, Man YB et al. (2007) Prevalence, awareness, treatment, and control of hypertension among United States adults 1999-2004. Hypertension 49, 69-75.

8. Fryar CD, Ostchega Y, Hales CM et al. (2017) Hypertension prevalence and control among adults: United States, 20152016. NCHS Data Brief issue 289, 1-8.

9. Song HJ \& Lee HJ (2014) Consumption of kimchi, a salt fermented vegetable, is not associated with hypertension prevalence. J Ethn Foods 1, 8-12.

10. Ministry of Health and Welfare \& Korea Centers for Disease Control and Prevention (2018) Korea National Health and Nutrition Examination Survey. https://knhanes.cdc.go.kr/ knhanes/eng/index.do (accessed August 2018).

11. Ministry of Health and Welfare \& Korean Nutrition Society (2015) 2015 Dietary Reference Intakes for Koreans. Seoul: Korean Nutrition Society.

12. Ministry of Health and Welfare (2015) Protocol for Nutrition Survey 2015. Cheongju: Korea Centers for Disease Control and Prevention.

13. Rural Development Administration (1996) Food Composition Table, 5th ed. Suwon: Rural Development Administration.

14. Rural Development Administration (2001) Food Composition Table, 6th ed. Suwon: Rural Development Administration.

15. Rural Development Administration (2006) Food Composition Table, 7th ed. Suwon: Rural Development Administration.

16. Rural Development Administration (2011) Food Composition Table, 8th ed. Suwon: Rural Development Administration.

17. Yon MY, Lee YN, Kim DH et al. (2011) Major sources of sodium intake of the Korean population at prepared dish level-based on the KNHANES 2008 \& 2009. Korean J Community Nutr 16, 473-487.

18. Kim S, Moon S \& Popkin BM (2000) The nutrition transition in South Korea. Am J Clin Nutr 71, 44-53.

19. Song DY, Park JE, Shim JE et al. (2013) Trends in the major dish groups and food groups contributing to sodium intake in the Korea National Health and Nutrition Examination Survey 1998-2010. Korean J Nutr 46, 72-85.

20. Kang YW, Hong KE, Choi HJ et al. (2007) Dining-out behaviors of residents in Chuncheon city, Korea, in comparison to the Korean National Health and Nutrition Survey 2001. Nutr Res Pract 1, 57-64.

21. Park C (2004) Efficient or enjoyable? Consumer values of eating-out and fast food restaurant consumption in Korea. Int J Hosp Manage 23, 87-94. 
22. Song Y, Park M, Paik H et al. (2010) Secular trends in dietary patterns and obesity-related risk factors in Korean adolescents aged 10-19 years. Int J Obes (Lond) 34, 48-56.

23. World Health Organization (2003) Diet, Nutrition and the Prevention of Chronic Diseases. Report of a Joint WHO/ FAO Expert Consultation. WHO Technical Report Series no. 916. Geneva: WHO.

24. Del Valle HB, Yaktine AL, Taylor CL et al. (2011) Dietary Reference Intakes for Calcium and Vitamin D. Washington, DC: National Academies Press.

25. Lee HS, Duffey KJ \& Popkin BM (2013) Sodium and potassium intake patterns and trends in South Korea. J Hum Hypertens 27, 298-303.

26. Kim MK \& Lee KG (2014) Consumer awareness and interest toward sodium reduction trends in Korea. J Food Sci 79, issue 7, S1416-S1423.

27. Ministry of Health and Welfare (2012) Master Plans for National Nutrition Management I (2012-2016). Sejong City: Ministry of Health and Welfare, Republic of Korea.

28. Park JS, Choi SB, Rhee Y et al. (2015) Parathyroid hormone, calcium, and sodium bridging between osteoporosis and hypertension in postmenopausal Korean women. Calcif Tissue Int 96, 417-429.

29. Ekinci EI, Clarke S, Thomas MC et al. (2011) Dietary salt intake and mortality in patients with type 2 diabetes. Diabetes Care 34, 703-709.

30. Kang MS, Kim CH, Jeong SJ et al. (2016) Dietary sodium intake in people with diabetes in Korea: the Korean National Health and Nutrition Examination Survey for 2008 to 2010. Diabetes Metab J 40, 290-296.

31. Kim HJ, Lim SY, Lee JS et al. (2010) Fresh and pickled vegetable consumption and gastric cancer in Japanese and Korean populations: a meta-analysis of observational studies. Cancer Sci 101, 508-516.

32. Jung KW, Won YJ, Kong HJ et al. (2018) Cancer statistics in Korea: incidence, mortality, survival, and prevalence in 2015. Cancer Res Treat 50, 303-316.

33. Kim HJ \& Oh K (2014) Methodological issues in estimating sodium intake in the Korea National Health and Nutrition Examination Survey. Epidemiol Health 36, 1-5.

34. Nam GE (2017) Consideration in analysis of nutrition survey data from Korea National Health and Nutrition Examination Survey. Korean J Fam Pract 7, 1-2. 